Educational Research for Social Change (ERSC)

Volume 9 No. 1, June 2020

pp. 78-91

ersc.nmmu.ac.za

ISSN: 2221-4070

\title{
The Rise of the Executive Dean and the Slide into Managerialism ${ }^{10}$
}

\author{
Sioux McKenna \\ Centre for Postgraduate Studies, Rhodes University \\ s.mckenna@ru.ac.za
}

\section{Abstract}

Universities have long been characterised by hierarchical and paternalistic management structures and institutional cultures. Change is therefore to be welcomed but, in contexts where social change is urgently needed, it is possible to mistake a change in any direction as being worthwhile. Around the world, recent shifts in university leadership and management have been towards managerialist approaches that work against a shared responsibility for the academic project. Accusations of managerialism often refer to a general sense that institutions are becoming bureaucratic, or that it is the logic of the market that drives decision-making. But beyond vague complaints, these accusations fail to identify the exact processes whereby managerialism takes hold of the institution. This article hones in on one specific example of institutional change in order to argue that it is implicated in the move towards managerialism: most universities in South Africa have changed from having elected deans, selected by faculty, to executive deans, appointed by selection committee. Crudely distinguished, it can be said that elected deans represent the interests of their faculty up into various institutional structures whereas executive deans are tasked with implementing the decisions of top management down into faculty. This paper tracks the differences between the two forms of deanship through reflections on discussions about such a change at one South African institution, Rhodes University. It analyses the literature to argue that we do not have to choose between patriarchal management and compliance-based managerialism. Instead, we can choose shared responsibility for the academic project.

Keywords: managerialism, executive deans, leadership, university management, collegiality

\section{Copyright: (c) 2020 McKenna}

This is an open access article distributed under the terms of the Creative Commons Attribution NonCommercial License, which permits unrestricted non-commercial use, distribution, and reproduction in any medium, provided the original author and source are credited.

Please reference as: McKenna, S. (2020). (2020). The Rise of the Executive Dean and the Slide into Managerialism. Educational Research for Social Change, 9(0), 78-91

http://dx.doi.org/10.17159/2221-4070/2020/v9i0a6

\footnotetext{
${ }^{10}$ This article was not based on any empirical data and so no ethical clearance was required by Rhodes University. The draft article was commented on by the vice-chancellor and deputy vice-chancellors and members of the ad hoc committee considering changes to the nature of appointment of deans.
} 


\section{Introduction}

Donella Meadows (2008), whose work underpins the focus of this special edition, "Dancing on the Waves of Change," argued that much of the reflective research work we need to undertake is qualitative in nature. If we do not undertake reflective qualitative research on our institutional systems and interrogate which interests they privilege, we can easily find ourselves making changes in problematic directions. She argued that changes often rest on the idea that "if you can't define it and measure it, you don't have to pay attention to it" (Meadows et al., 1972, p. 55). This journal, Educational Research for Social Change, takes as its premise however that not everything that counts can be counted.

Meadows (2008, p. 170) also asserted that "before you disturb the system in any way, watch how it behaves. ... Before you charge in to make things better, pay attention to the value of what's already there." In a context such as the South African higher education system with its inherent injustices and racialised structures, it is easy to think that charging in and making change is necessary-regardless of the nature of such change. While many of the changes experienced in the sector have been good, such as the changes over the last three decades in the direction of widening access, and we should celebrate such changes, we also need to be cautious of the direction in which certain institutional shifts are taking us. Around the world, changes in university systems have often been conceptualised as managerialist. This ideology is identified as underpinning universities' structures and practices (Deem, 1998; Kinman, 2014; Thys-Clent et al., 2002). In a nutshell, managerialism entails managing every aspect of the academic endeavour in order to ensure better efficiencies. It assumes that business concepts can be imported into universities to ensure financial stability.

This article reflects on changes towards managerialism in our institutions by considering one specific example: the move from elected deans to executive deans - a move that has already taken place across most South African universities. In this reflective piece, I consider the relevant literature to show how the role of executive dean needs to be understood as one small step in a much broader shift towards managerialism in the university sector, a shift that we need to navigate with caution.

\section{The Managerialist University in an Era of Efficiency}

Drawing largely on international literature, we can see that managerialism is driven by cost-benefit thinking (Bok, 2009; Giroux, 2014; Newfield, 2016). Clearly, the cost-effectiveness of the university's internal processes is significant but, in a managerialist institution, this logic pervades even the purpose of the university, which then entails pandering to the demands of external markets in the name of sustainability. The university becomes conceptualised as an institution focused on producing skills and goods for the market, rather than as a public good focused on knowledge creation and the nurturing of critical citizens who are well placed to address environmental degradation and social injustice. The focus on the production of skills and goods for the market has consequences for teaching, research, community engagement, and every other university activity.

The market logic of managerialism suggests that efficiencies are enhanced through competition (Deem, 2001; Nixon, 2010). This leads to employees being encouraged to be competitive and being rewarded on the basis of their outputs rather than their contribution. Giroux (2014) argued that we can see what he called the neoliberal move through internal markets being introduced within the institution, for example, when departments are run as individual cost centres that have to pay for the hiring of institutional venues, or when financial incentives are paid to star performers for their research outputs, and when less financially significant tasks, such as pastoral care of students, are rendered invisible. Management's role of developing a commitment to a shared endeavour and then trusting people to work towards it is replaced with the surveillance and performance measurement of labour 
(Giroux, 2014). Working in a university that is premised on adherence to rules, rather than on the stewardship of academic values, can lead to a lack of commitment to anything that is not explicitly required in the job description (Maistry, 2012).

In a managerialist university, labour is measured by exchange value, rather than use value (Harley, 2017). Use value entails valuing labour that "produces useful things, things that are necessary for our existence and well-being" (Harley, 2017, p. 1). Exchange value, on the other hand, cares not whether the work has been for the public good, has been undertaken with care and compassion, or whether the work has meaning in the world; instead, exchange value is concerned with whether the product of the work can be sold for more than the cost of the time and materials taken to produce it (Holloway, 2010). Around the world, the validating of academic labour on the basis of exchange value has had the effect of alienating those working and studying in the academy (Bok, 2009; Giroux, 2014).

There is alienation from the academic project when teaching comes to be discussed as the number of FTEs ${ }^{11}$ accrued for enrolment and graduation, rather than as the transformation and empowerment of people, and when research comes to be viewed through the metrics of subsidised outputs, rather than as contributions to knowledge. This thinking has resulted in the development of a "short-term approach to research, an emphasis on articles and deliverables" (Shore, 2010, p. 25), where the "thrill of discovery is ... held in check by the need to package yourself as a saleable commodity" (Nash, 2013, p. 43). As Deem (1998, p. 48) explained of universities in the United Kingdom:

\begin{abstract}
Universities are . . being exhorted to raise both the standards of educational provision, and the quality of their teaching, learning and research outcomes, whilst prevailing government policies also require annual so-called "efficiency gains" to be made, resulting in a declining unit of resource per student taught, less money for equipment and a decrease in research resourcing. At the same time, the emphasis on competition between universities for students, research income and academic research "stars," has also served to stress the extent to which higher education can be described as operating under quasimarket conditions.
\end{abstract}

There is an argument that those who resist the processes of the managerialist university, such as the performance management of academics, are simply doing so because their lack of productivity would be exposed through such systems. But this argument underestimates the extent to which such shifts impact on every relationship in the university and, indeed, the whole ethos of academic life (Nash, 2013). The professor who publishes regularly and supervises numerous postgraduate scholars is doing the kind of work that performance management systems reward with status and financial payment (Waitere et al., 2011), but she is still harmed by such systems. Any benefits that such an academic might accrue would not be shared with colleagues who do the bulk of undergraduate teaching or with those who are novice researchers. Performance management systems encourage activities that are "calculable rather than memorable" (Ball, 2012, p. 17), and can have numerous unintended consequences such as the adaptation of teaching and assessment practices to allow more time for research (Ball, 2016), and the rise of predatory publications in a bid to receive funding incentives rather than publishing in order to disseminate knowledge (Mouton \& Valentine, 2017).

The managerialist turn positions the university as being in the business of the production of goodsboth graduates and knowledge. This process gets into "our minds and souls" (Ball, 2012, p. 4); it affects our values, our approach to teaching, our relationship with our students and with our colleagues. In all these areas, we're encouraged to "replace commitment with contract" (Ball, 2012, p. 20). In line with a consumerist ideology, the managerialist university embodies the ethic of competitive, individual self-

\footnotetext{
${ }^{11}$ FTEs, or full-time equivalent students, are the weighted measurement by which the State funds universities in South Africa.
} 
advancement. In order to excel in the managerialist university, academics should focus on developing a very niche area of expertise, they should publish on their own, and they should eschew teaching (Newfield, 2016).

South African universities were latecomers to managerialist processes that have been widely critiqued elsewhere (Hedley, 2010; Sandgren, 2012; Smeenk et al., 2009; Teelken \& Deem, 2013). In part, we were protected by the public good roles articulated for the university in the larger national reconciliation project (Department of Education, 1997), but the power of the "knowledge economy" discourse means that our institutions are increasingly seen to be sophisticated training grounds providing the skilled labour needed for economic growth. The extremely challenging financial context of South African institutions has also been a key driver of managerialism because such processes promise efficiency and financial stability - though there is little evidence that they provide it (Ginsberg, 2011).

Some argue that changes in how our universities are run are not managerialist per se but, rather, are a much-needed strengthening of management. It is inarguable that many institutions in the South African sector battle with problems of weak leadership and shoddy management. This is evidenced, not least, in the all too regular placement of institutions under administration over the last decades (National Planning Commission, 2011), the ongoing stories of corruption, and the general lack of capacity in core areas - such as the inability of most institutions to spend grants allocated for the improvement of teaching and research, resulting in millions of rand being reclaimed by the Department of Higher Education and Training every year (Moyo, 2018). But pointing out the problems of poor management is not an argument for managerialism. While strong management can take many different forms, from inspirational leadership to administrative competence, managerialism entails one very particular ideological position: that the academic project needs to be tightly controlled by those who are external to the actual academic work.

The potential for a humanising dialogue (Roux \& Becker, 2016) in our universities is severely constrained by the more hierarchical notion of the university where management is understood to be entirely separate from the academic body, such that there is "a serious gap between leaders and managers on the one hand and academics on the other" (de Boer \& Goedegebuure, 2009, p. 356). This rift between management and those engaged in the academic endeavour is enacted through small structural changes in our institutions such as the introduction of numeric measurements of performance, the decreasing authority of Senate, and the increase in powerful institutional positions outside of academic faculties (Bok, 2009; Ginsberg, 2011; Newfield, 2016).

Concerns about the incursion of managerialism are often expressed in vague terms and there is little understanding of the specific institutional changes that lead to its emergence. There is no checklist for a managerialist institutional culture but being able to identify specific examples of moves towards managerialism is key to our being able to resist it. The introduction of executive deans is not, in itself, an indicator of the "managerialist university." Nonetheless, I think consideration of the appointment of executive deans offers a useful case study through which to consider the emergence of managerialism. It is an issue with which the university where I work is currently engaged.

\section{A Small University in a Small Town}

Until recently, Rhodes University was the smallest university in South Africa. This identity has been usurped by a number of newly formed institutions that are still enrolling to their full capacity. Rhodes University has not resisted its small nature-indeed, it has often protected it. In large part, this is because the municipality cannot cope with serving a larger population in the rural town in which the 
university exists. The infrastructure to provide consistent water supply, electricity, housing, and functional roads is already stretched. But besides such external constraints, there are numerous advantages to being small. There are, for example, pedagogical benefits to being a small university in a small town where academics and students cross paths in various spaces on campus and off, and where the deans know many of their students by name (Case et al., 2018). The small size of the university may well be part of the reason why the university consistently enjoys among the best undergraduate throughput rates and per capita research outputs in the country.

Along with the rest of the sector, the university is grappling with massification in an era when government subsidy has failed to keep up with inflation. Massification, according to the seminal article by Trow (1994), occurs when a national higher education system is accessed by at least $15 \%$ of youth between the ages of 18 and 23 years old. South Africa has now reached a participation rate of over $20 \%$ (Council on Higher Education [CHE], 2019). Massification is about far more than large student numbers. A massified student body no longer comprises only wealthy and middle-class students. Many students will be seeking higher education with the hopes of social mobility, they will not necessarily have strong schooling backgrounds, they will not necessarily have access to literacy practices that align fairly closely to those of the university, and they will bring prior knowledge that may be overlooked or dismissed by the university curriculum in alienating ways. These are just some of the implications of massification for both teaching and learning; the implications for the academic leadership and management of our institutions are just as profound. Many leaders battle to meet the needs of the changed student body and our institutions might be poorly placed to ensure that equity of access is met with equity of outcomes. Increasing the numbers of students who enter higher education, that is, achieving equity of access is, in many ways, the easier goal to attain. Equity of outcomes, that is, supporting students to succeed, is far trickier-as the persistence of racially differentiated success rates across all our institutions indicates (CHE, 2019).

A particular challenge is that these demands take place in a context of institutional fiscal constraint. Financial issues have taken a sharp form in this particular university for a few reasons. Firstly, the institution fails to benefit from economies of scale. Secondly, it made the very expensive but principled decision over the last decades not to outsource a great many of its departments such as maintenance, gardening, catering, residences, and others, while every other university in the country cut costs by doing so. Thirdly, it made another financially costly but principled decision to, since the early 2000s, use its own resources to top up National Student Financial Aid Scheme (NSFAS) fees (NSFAS, n.d.) and increase the threshold to better meet the demand for higher education from academically deserving but financially needy students. For these and other reasons, this university now faces cost-cutting measures despite offering amongst the lowest academic salaries in the country.

Understanding the context of an institution is important for any analysis of its structure and culture. Rhodes University, with its history of whiteness and privilege (Maylam 2017), is well positioned in its rural setting to make changes in its scope and focus while attending to its responsibilities as a researchintensive institution. The need to move from a patriarchal institutional culture to a socially just culture focused on shared academic endeavour is intensely felt in this little university, and a number of initiatives have been put in place to attend to its multiple responsibilities as a research-intensive university in a rural setting in which many people experience poverty (Rhodes University, 2018, 2019).

It is in this context of ongoing institutional change that faculty boards have been discussing the possibility of following other universities in South Africa and moving from a system of elected deans to the appointment of executive deans. A key driver of this debate is that fewer and fewer people want to take on the role of leader of the faculty in the context of the increased administrative demands attached to the post. Taking on the role of dean is no longer seen as an honour so much as a burden. 
The need for more demographically representative leadership is strongly felt. At present, the deans of the six faculties comprise three white men, two white women, and one black man. Only a limited number of internal academics can take on the role and some are understandably concerned about the constraining implications being dean has for their own research endeavours.

While I have been consistently opposed to implementing this change at Rhodes University (see, for example, McKenna, 2015, 2018), there are undeniably some benefits to introducing executive deans. In order to make sense of them, we need to have clarity as to the distinction between the two forms of deanship.

\section{The Difference Between an Elected and an Executive Dean}

Simply put, an elected dean is appointed through a vote by faculty whereas an executive dean is appointed through the usual institutional appointment processes. There are, however, a number of additional differences that distinguish these two forms of deanship, to which I now turn.

The elected dean is considered to be primus inter pares (the first among equals; de Boer \& Goedegebuure, 2009) and is nominated by faculty members who then vote once the academic has agreed to such nomination. The elected dean can stand for a second term of office (and, in some cases, a third or more). The faculty has the right to reappoint the incumbent dean or to appoint someone else, or to vote between the existing dean and another candidate. The faculty also has the right to insist that a dean step down if there is a vote of no confidence in her performance.

In contrast to this, the executive dean is appointed by a committee that would include some faculty representation but would also include whatever representation is the institutional norm for management appointments such as vice-chancellor, deputy vice-chancellors, human resources director, other executive deans, trade unions, and so forth. Most of these people would have little or no role to play in the appointment of an elected dean. Like the elected dean, the executive dean takes on the role for a fixed time period. Renewal of the contract for an additional period, however, is not up to the faculty but is dependent on the executive dean meeting the performance management criteria attached to the position.

The job description of the elected dean is often relatively informal and relates to her offering guidance and leadership to the faculty and her representing the voice of the faculty on various institutional structures (de Boer \& Goedegebuure, 2009). Typically, the elected dean is paid an allowance on top of her salary for the duration of her term of office. She loses this allowance when she returns to her fulltime academic post after her tenure as dean.

Executive deans, on the other hand, are paid large salaries in South Africa, and these are typically pegged at the top administration salary scales with a significant pay grade difference between the executive dean's salary and those of academics. The executive dean salary is closely aligned to the corporate nature of the job description, which would require high-level management expertise including the ability to manage those in the faculty in line with institutional demands.

The elected dean is expected to be a senior academic with recognition from the faculty emerging, in part, from her active engagement in teaching and learning, research, and community engagement. The elected dean often continues to produce academic research and undertake postgraduate supervision and, sometimes, also teaches during her tenure as dean. She thus has the mammoth task of juggling her academic demands alongside the management ones. 
The academic background of the executive dean, on the other hand, is not the core basis on which she is employed. She is not generally expected to do any teaching and, in many cases, undertaking research is not a requirement either. However, the ability to raise funds for research projects, infrastructure, and so on is often explicitly stated in the performance management contract (Seale \& Cross, 2016).

While both kinds of dean are expected to oversee teaching and learning, and the faculty's relationship to its students, the executive dean is also expected to take on a number of other roles. These include the responsibility for aligning faculty strategy to institutional processes, performance management of staff, external stakeholder relationship management, marketing of programmes, and the development of third-stream income sources (de Boer \& Goedegebuure, 2009). The elected dean might also engage with such activities but these would generally be collaboratively undertaken with broader faculty representation. Having an elected dean thus requires more involvement in various projects by all staff in the faculty, projects that may simply be presented to faculty as faits accompli in the case of executive deans.

While both kinds of dean are expected to identify closely with the needs of the students and academics, balanced by responsibilities to the institutional management team, and, in some cases, the relevant professional body, the executive dean holds such responsibilities with a significantly different weighting and she responds to a much more multifaceted constituency. For example, "executives are actively engaged in setting institutional objectives and measuring outputs. New instruments, frequently copied from the private sector, such as benchmarking, internal performance agreements, and reporting and monitoring systems are no longer the exception but the rule" (de Boer \& Goedegebuure, 2009, p. 351). And while executive deans might have a say in developing an institution's policies and approaches, once these are agreed upon by management structures, the executives have a responsibility for implementing them regardless of their perspectives on the issue. They may thus have to navigate a disjuncture between their own views and those they are expected to officially espouse (Waghid, 2000). Those "schooled in social justice theory are likely to experience several tensions when they assume leadership roles in higher education" (Maistry, 2012, p. 515).

The discussion, thus far, of the differences between the two forms of dean has attempted to make the distinctions explicit but there is, of course, much variability depending on factors such as the type, status, and size of the institution and the country's higher education policies and processes (de Boer \& Goedegebuure, 2009). South African universities are highly differentiated by history and also by type: traditional universities, comprehensive universities, and universities of technology. Both differentiation of history and differentiation of type lead to very different institutional cultures, which impact on how deanship is conceptualised and enacted. How hierarchical the university is, the institutional expectations about leadership and management, and the extent to which academics have the autonomy to determine the structures and practices of the university (Bozalek \& Boughey, 2012; McKenna \& Boughey, 2014) all impact on the nature of deanship in that university. White et al. (2011, p. 181) argued, for example, that "universities of technology are much more managerial with centralised power located with the VC, and comprehensive universities (that offer both research-based degrees and practically oriented diplomas) are also more managerial and centralised." They pointed out that, in contrast, fairly significant power is devolved to the dean and faculty in some universities in the sector. Seale and Cross (2018, p. 276) argued that, regardless of institutional history or type, the introduction of the executive dean in Gauteng

added another layer of complexity to deanship . . . and points to a potential crisis in the advancement of the academic project, since the position of dean is now more management orientated, and allows little or no room for strategic academic leadership. 


\section{Elected Deans for the Status Quo and Executive Deans for Change?}

The main argument against elected deans is that they are steeped in the culture of the faculty they lead, including aspects thereof that are resistant to transformation. Research suggests that where management is undertaken with a light touch because academics are expected to be committed to a shared endeavour and are therefore "trustworthy," academics can abuse this freedom to avoid transformation (McKenna \& Boughey, 2014). The patriarchal university is reliant on systems of patronage disguised as collegiality and the elected dean may potentially form the linchpin for such power networks, or old boys' clubs that privilege particular sets of voices and values while silencing others. The patriarchal university suffers from class elitism, racism, and sexism, a lack of accountability, and very little transparency (Nash, 2013). Given the enormous demands for change across areas such as curriculum, institutional culture, and staff demographics (CHE, 2016), this is a significant concern.

But, it is important to note that the literature suggests that the move from patriarchal universities to managerialist ones has not done away with systems of patronage (Maistry, 2012). Arbitrary decisions and preferential treatment, which used to be quietly implemented via the network of power in the patriarchal university, are, in the managerialist university, justified in circumlocutory ways in which managers "rely on legal technicalities or on legal procedures that will bankrupt colleagues who stand up to them" (Nash, 2013, p. 45).

The argument that elected deans are resistant to change, whereas executive deans will drive the transformation agenda, is based on two problematic assumptions. It assumes that elected deans are always invested in the status quo rather than committed to a more socially just institutional culture, and it assumes that the changes brought about by executive deans would be in the interests of the academic project and transformation. Executive management structures, however, generally focus on internal reporting, performance monitoring, and quality assurance processes (Shore, 2010; Shore \& Wright, 2015; Strathern, 2000), rather than bolstering a more socially just academic project. There is ample evidence that one of the core roles of executive management in times of fiscal constraint is to implement rationalisation processes (Joseph, 2015; Wolverton et al., 1999) and to build income diversification rather than to attend to the racialised structures of power in the university (Taylor \& Taylor, 2010). Executive deans are more likely than elected deans to embrace managerial values, because "the balance between academic and managerial values seems to tip towards the latter" (de Boer \& Goedegebuure, 2009, p. 354) and the position of executive deans in South Africa is "skewed towards the executive, administrative, management dimensions, with little if any support for strategic advancement of the academic project" (Seale \& Cross, 2018, p. 288).

Maistry (2012) argued that because executive staff members are typically only part of the university community for the duration of their contracts, and they are driven by the need to deliver on performance management outputs, they may be more likely to coerce faculty and suppress dissent. He emotively argued that the "ingenuity of temporality is that the perpetrators do not remain on long enough to witness the long-term damage that is the product of their acts" (Maistry, 2012, p. 521).

The argument that the appointment of executive deans is necessary for transformation was also challenged by research undertaken by Michael Cross and others. Johnson and Cross (2004) argued more than a decade ago that the introduction of the executive dean in South Africa would work against the institutional rejuvenation agenda and then, in 2018, Seale and Cross asserted that, at least for the universities in their study, this was indeed the case. There is no research to show that the appointment of executive deans has brought about system efficiencies and increased funding in the form of project grants even though very large salaries have been paid to this end. Indeed, Seale and Cross argued that the introduction of executive deans has "contributed very little to the envisaged long-term and farreaching operational efficiency and effectiveness" (2018, p. 276). 


\section{Attracting External People to Managerialist Positions}

The South Africa higher education sector is a small one and we know from the lengthy time period taken to fill posts that there is not a glut of qualified candidates waiting to be lured into these jobs. Top-level managers with the cut-and-thrust business acumen to drive profitable changes are more likely to be drawn to the salaries of industry than those offered by our universities. And for those who are attracted not so much by salary as the desire to provide meaningful leadership of the academic project, the incursion of managerialism makes academia a far less desirable career option (Waitere et al., 2011).

In an era where we are trying to attract young academics, particularly black South Africans, to academia, it seems problematic to be embracing systems that undermine the very essence of what is worthwhile in working in a university, that is, engaging in the academic project, participating in an endeavour that has extensive use value, being part of knowledge creation and dissemination, and contributing to a public good. Maistry went so far as to argue that the "reckless appropriation of neoliberal, western performance-driven models grounded in economic rationalism translates into a form of subtle and sometimes overt 'violence' against, and humiliation of, marginalized individuals and groups within the university community" (2012, p. 515).

The term "executive" in the designator has significance. ${ }^{12}$ Executives belong to top management structures, which are positioned by this terminology as being separate from those on the ground engaged in the academic project. The executive dean has executive powers and can give executive orders. Importantly, such positions are often accompanied by the introduction of a number of other high-level administrative positions (de Boer \& Goedegebuure, 2009) such as executive director of human resources, executive director of intellectual property and technology transfer, executive director of risk management, executive director of institutional planning, executive director of quality assurance, and so the list goes on. Individually, such positions can be argued to be necessary for enhanced efficiencies in the institution but, collectively, they shift the culture of the organisation away from the academic project (Ginsberg, 2011). Taylor and Taylor (2010, p. 897), writing about South Africa, indicated that "over the last two decades or so, a new managerialism has indeed witnessed academics surrendering power and authority to a new breed of professional, highly-paid, and bureaucratically-inclined university administrators."

Habib (2013) called for proactive engagement with the increasingly market-orientated positioning of university activities with a view to subverting from within. He suggested that this would entail using market strategies to ensure that institutional power and status remain with academics through initiatives such as awards and non-pensionable allowances paid to high performing academics so that senior executives are not the only power brokers. Habib's response to those critics, such as myself, who argued that these approaches are succumbing to the logic of the market, is that we are out of touch with the realities of the moment and we should not confuse means and ends. Coughlan (2008, p. 582) similarly suggested that "a balance is needed between collegial and more corporate style management if a university is to protect its academic work while surviving in an external environment that could be perceived to be increasingly hostile to the traditional collegial model."

Taking on any management role in these politically charged times, when the very nature of the university is under debate, is an onerous task. Increasingly faculty members are not willing to raise their hands to be considered for election as dean. Thus, the ponderings presented here about the

\footnotetext{
12 In a few cases in South Africa, the word "executive" is not used in the title, possibly because of the negative connotations of the word or in order to avoid paying the large salaries typically associated with the term. However, the position remains "executive dean" in the sense of fulfilling the key characteristics outlined in this article.
} 
managerialist implications of executive deanships may well be moot. If nobody is willing to stand for election, there is no option but for Rhodes University to follow the rest. Unless there is an explicit understanding within the institution of why a culture of collaborative leadership is worth nurturing, it is unlikely to flourish.

\section{A Different Way}

There is no doubt that the patriarchal university characterised by systems of patronage must be dismantled, and that multiple small shifts have taken place to bring about the changes we can celebrate today. However, we do not need to choose between an unjust historical system and a future managerialist one. The possibilities for an ethical university based on an ongoing commitment to the academic project are evident all around us. But this requires a willingness by everyone to share responsibility for the institution's actions.

Working in the managerialist institution may be far less intellectually, socially, and morally rewardingbut it can also be far simpler. It absolves university employees from doing anything beyond the tight confines of their output-measured and quality-assured job descriptions. It allows disgruntled employees to blame "management" for any unpopular institutional decisions. Managerialist institutions empower the top echelons of the hierarchy at the expense of the projects of the rest, and thereby withdraw agency from "the rest" for driving change. The job of the rest then becomes compliance to the outcomes set in the performance management systems, rather than personal commitment to the academic endeavour.

Centralisation of power and decision-making within universities, and reluctance or fear to challenge management decisions leads to an insidious culture of compliance (Shore, 2010) whereby academic freedom is quietly curtailed. Academics' voices are "managed" to ensure they do not make statements that could besmirch the branding of the institution. Management teams then speak on behalf of the university relegating "staff, alumni and students to the role of 'stakeholders' -along with students, parents, industry, and government. This discursive turn represents a major shift in power relations" (Shore, 2010, p. 26).

Collaborative decision-making, where the university's decisions are determined in favour of the academic project, requires an explicit joint accountability ethos (Maistry, 2012) where everybody working in the university is responsible for its endeavours. It's a significant challenge and one that requires an institutional culture at odds with the direction being taken by many universities. The small size of the university upon which this reflection is focused makes it perfectly placed to exemplify the ethical university, and many of its current activities provide a rich resource base from which to work, but it will need to be much more explicit in its endeavours in this regard.

\section{Conclusion}

If this argument against executive deans is convincing, then the key challenge may be to facilitate a system whereby external people can be elected by faculty into dean posts, given the need for transformation and for more flexibility beyond the small number of potential internal candidates. As noted above, the elected dean is typically an internal appointment from existing staff members whereas the executive dean is typically an external appointment. This seemingly simple issue may well be a sticking point between the two systems. In principle, internal staff can apply for an executive dean position and, conversely, faculty can approach external candidates to stand for election as elected deans, though this is complicated by the need for a vacant academic position that an external elected dean could fill. If we could navigate the need for any elected dean from outside the university to be assured a permanent academic position after their term of office, this problem could be ameliorated. 
But, beyond such practicalities, the deliberations about a shift from elected to executive deans at one university require us to reflect on the relationship between structures and cultures in our universities, more generally. I have argued that the structural move from elected dean to executive dean entails far more than a shift in appointment procedures. It is part of a broader incursion of managerialist culture into our universities.

Because institutional cultures are, by nature, implicit, it is difficult to engage in deliberation about them. "Ambivalence is an effect of all of this, the sense of not being clear enough about what is worthwhile, what is defensible and what is objectionable" (Ball, 2012, p. 24). We need conversations about the nature of the academic project in each of our universities and the responsibility of everyone who works in the university to this project. We are guided to some degree by national policy but we need to have a clearer sense of the academic project at each university and an explicit understanding of how it is that every person who works in the institution serves that project, whether they are academic, administrative, support, or management. This process of explicit conversations about institutional culture and the academic project will also have implications for how students participate in the university.

Alongside the challenges of making institutional cultures explicit, comes the issue that no university works in isolation of the bigger context. It is almost impossible for a particular institutional culture to exist in contradiction to broader national and international cultural and structural conditions (Archer, 2007). Habib (2013, p. 66) argued that it is "going to be impossible to create islands of collegiality in a market-oriented higher education system. This is especially so since universities are funded by the state by means of a formula that is itself market-oriented."

Is resistance futile? Is it dangerously naïve? Or is it up to those of us committed to the academic project as a public good to defend the university from becoming yet another tool of the market? If we want our universities to instil "values of empathy and mutual recognition, compassion, respect, dignity and meaningful relationships with peers" (Walker, 2005), then we need to ensure that the very fabric of our institutions is made of these (Walker \& Wilson-Strydom, 2016). Perhaps there is some truth in the accusations that resisting the managerialist university comes from self-interest or a romanticising of something that has never existed. But there is also the truth that many of us have a deep-seated commitment to the role of the university in knowledge creation and dissemination, and a determination that this should underpinned by a principle of public good for people and the planetnot profit.

\section{References}

Archer, M. S. (2007). Making our way through the world: Human reflexivity and social mobility. Cambridge University Press.

Ball, S. J. (2012). Performativity, commodification and commitment: An I-spy guide to the neoliberal university. British Journal of Educational Studies, 60(1), 17-28.

Ball, S. J. (2016). Neoliberal education? Confronting the slouching beast. Policy Futures in Education, $14(8), 1046-59$.

Bok, D. (2009). Universities in the marketplace: The commercialization of higher education. Princeton University Press.

Bozalek, V., \& Boughey, C. (2012). (Mis)framing higher education in South Africa. Social Policy \& Administration, 46(6), 688-703. 
Case, J., Marshall, D., McKenna, S., \& Mogashana, D. (2018). Going to University: The Influence of Higher Education on the Lives of Young South Africans. African Minds

Coughlan, F. J. (2008). Bridging the divide: Managed managerialism. South African Journal of Higher Education, 20(5), 582-591.

Council on Higher Education. (2016). South African higher education reviewed: Two decades of democracy.

https://www.academia.edu/32279151/HIGHER EDUCATION REVIEWED Two Decades Of Dem ocracy South African

Council on Higher Education. (2019). VitalStats: Public higher education 2017. https://www.policysa.com/images/VitalStats Public\%20Higher\%20Education\%202017.pdf

de Boer, H., \& Goedegebuure, L. (2009). The changing nature of the academic deanship. Leadership, 5(3), 347-64.

Deem, R. (1998). "New managerialism" and higher education: The management of performances and cultures in universities in the United Kingdom. International Studies in Sociology of Education, 8(1), 47-70.

Deem, R. (2001). Globalisation, new managerialism, academic capitalism and entrepreneurialism in universities: Is the local dimension still important? Comparative Education Review, 37(1), 7-20.

Department of Education. (1997). Education white paper 3: A programme for the transformation of higher education.

https://www.gov.za/sites/default/files/gcis document/201409/18207gen11960.pdf

Ginsberg, B. (2011). The fall of the faculty. Oxford University Press.

Giroux, H. A. (2014). Neoliberalism's war on higher education. Haymarket Books.

Habib, A. (2013). Reflections of a university bureaucrat interested in advancing a progressive social agenda. Kagisano, 9, 63-74.

Harley, A. (2017). Alienating academic work. Education as Change, 21(3), 1-14.

Hedley, S. (2010). Managerialism in Irish universities. Irish Journal of Legal Studies, 1(1), 117-141.

Holloway, J. (2010). Crack capitalism. Pluto Press.

Johnson, B., \& Cross, M. (2004). Academic leadership under siege: Possibilities and limits of executive deanship: Perspectives on Higher Education. South African Journal of Higher Education, 18(2), 3458.

Joseph, R. (2015). The cost of managerialism in the university: An autoethnographical account of an academic redundancy process. Prometheus, 33(2), 139-63.

Kinman, G. (2014). Doing more with less? Work and wellbeing in academics. Somatechnics, 4, 219235.

Maistry, S. M. (2012). Confronting the neo-liberal brute: Reflections of a higher education middle-level manager. South African Journal of Higher Education, 26(3), 515-28.

McKenna, S. (2015, October 20). Five trends South African universities must reject if they really want change. The Conversation. https://theconversation.com/five-trends-south-africas-universitiesmust-reject-if-they-really-want-change-49452

McKenna, S. (2018, March 23). Here are five signs that universities are turning into corporations. The Conversation. https://theconversation.com/here-are-five-signs-that-universities-are-turning-intocorporations-93100 
McKenna, S., \& Boughey, C. (2014). Argumentative and trustworthy scholars: The construction of academic staff at research-intensive universities. Teaching in Higher Education, 19(7). DOI: $10.1080 / 13562517.2014 .934351$

Meadows, D. H. (2008). Thinking in systems: A primer. Chelsea Green.

Meadows, D. H., Meadows, D. L., Randers, J., \& Behrens, W. (1972). The limits to growth. Universe Books.

Mouton, J., \& Valentine, A. (2017). The extent of South African authored articles in predatory journals. South African Journal of Science, 113(7/8). https://doi.org/10.17159/sajs.2017/20170010

Moyo, S. (2018). An analysis of the implementation of the teaching development grant in the South African higher education sector [unpublished doctoral thesis]. Rhodes University.

Nash, A. (2013). Excellence in higher education: Is there really no alternative? Kagisano, 9, 42-62.

National Planning Commission. (2011). National Development Plan: Vision for 2030. https://cisp.cachefly.net/assets/articles/attachments/36224 npc national development plan vi sion 2030 -lo-res.pdf

National Student Financial Aid Scheme. (n.d.). Annual Reports. http://www.nsfas.org.za/content/annual-reports.html

Newfield, C. (2016). The great mistake: How we wrecked public universities and how we can fix them. Johns Hopkins Press.

Nixon, J. (2010). Higher education and the public good: Imagining the university. Bloomsbury.

Rhodes University. (2018). Institutional development plan 2018-2022: Transformation, sustainability, local relevance \& global impact. https://www.ru.ac.za/media/RHODES UNIVERSITY IDP.pdf

Rhodes University. (2019). Rhodes University institutional transformation plan 2019-2022. https://www.ru.ac.za/media/rhodesuniversity/content/equityampinstitutionalculture/document s/ITP Final Draft (004).pdf

Roux, C., \& Becker, A. (2016). Humanising higher education in South Africa through dialogue as praxis. Educational Research for Social Change, 5(1), 131-43.

Sandgren, A. (2012). Managerialism and entrepreneurialism in universities. In L. Wikander, C. Gustafsson, \& U. Riis (Eds.), Enlightenment, creativity and education: Polities, politics, performances (pp. 149-169). Sense.

Seale, O., \& Cross, M. (2016). Leading and managing in complexity: The case of South African deans. Studies in Higher Education, 41(8), 1514-1532.

Seale, O., \& Cross, M. (2018) Executivism and deanship in selected South African universities. Oxford Review of Education, 44(3), 275-290.

Shore, C. (2010). Beyond the multiversity: Neoliberalism and the rise of the schizophrenic university. Social Anthropology, 18(1), 15-29.

Shore, C., \& Wright, S. (2015). Governing by numbers: Audit culture, rankings and the new world order. Social Anthropology, 23(1), 22-28.

Smeenk, S., Teelken, C., Eisinga, R., \& Doorewaard, H. (2009). Managerialism, organizational commitment, and quality of job performances among European university employees. Research in Higher Education, 50(6), 589-607.

Strathern, M. (2000). Audit cultures: Anthropological studies in accountability, ethics, and the academy. Rouledge. 
Taylor, Y., \& Taylor, R. (2010). Academic freedom and racial injustice: South Africa's former "open Universities." South African Journal of Higher Education, 24(6), 897-913.

Teelken, C., \& Deem, R. (2013). All are equal, but some are more equal than others: Managerialism and gender equality in higher education in comparative perspective. Comparative Education Review, 49(4), 520-35.

Thys-Clent, F., Dewatripont, M., \& Wilkin, L. (Eds.). (2002). European universities: Change and convergence? Éditions de l'Université de Bruxelles.

Trow, M. (1994). Managerialism and the academic profession: The case of England. Higher Education Policy, 7, 11-18.

Waghid, Y. (2000). Notions of transformative possibility: Equality, accountability, development and quality within higher education. South African Journal of Higher Education, 14(3). DOI: 10.4314/sajhe.v14i3.50167

Waitere, H. J., Wright, J., Tremaine, M., Brown, S., \& Pausé, C. J. (2011). Choosing whether to resist or reinforce the new managerialism: The impact of performance-based research funding on academic identity. Higher Education Research \& Development, 30(2), 205-17.

Walker, M. (2005). Higher education pedagogies. McGraw-Hill Education.

Walker, M., \& Wilson-Strydom, M. (2016). Socially just pedagogies, capabilities and quality in higher education: Global perspectives. Palgrave Macmillan.

White, K., Carvalho, T., \& Riordan, S. (2011). Gender, power and managerialism in universities. Journal of Higher Education Policy and Management, 33(2), 179-88.

Wolverton, M., Wolverton, M. L., \& Gmelch, W. H. (1999). The impact of role conflict and ambiguity on academic deans. The Journal of Higher Education, 70(1), 80-106. 